Ambiente \& Água - An Interdisciplinary Journal of Applied Science
ISSN 1980-993X - doi:10.4136/1980-993X
www.ambi-agua.net
E-mail: ambi-agua@agro.unitau.br

\title{
Accumulation and recovery capacity of heavy metals in sand mine ponds of the Otamiri River in Owerri, Nigeria
}

\author{
doi: 10.4136/ambi-agua.1226
}

Received: 22 Oct 2013; Accepted: 22 Feb. 2014

\author{
Dike Henry Ogbuagu* ; Comfort Barikpoa Samuel \\ Federal University of Technology, Owerri, Imo State, Nigeria \\ Department of Environmental Technology \\ *Corresponding author: e-mail: henrydike2002@yahoo.com, \\ commykids@yahoo.com
}

\begin{abstract}
This study investigated the levels, index of accumulation and recovery capacity of heavy metals $(\mathrm{Pb}, \mathrm{Cd}, \mathrm{Cu}, \mathrm{Ni}, \mathrm{Zn}, \mathrm{Fe}, \mathrm{Mn})$ in sand mine ponds of the Otamiri River in Owerri, Nigeria during the wet season of 2012. Water (WC) and sediment samples (SD) were collected from six sampling points, with WC 1-WC 3 and SD 1-SD 3 located within a derelict mine pond and WC 4-WC 6 and SD 4-SD 6 located within an actively mined pond. The pH was determined in situ and levels of heavy metals measured with the atomic absorption spectrophotometer. The student's t-test, index of geoaccumulation $\left(\mathrm{I}_{\mathrm{geo}}\right)$, accumulation factor (AF) and pond recovery capacity (PRC) were computed for the ponds. There was significant spatial heterogeneity in mean levels of the heavy metals in sediments (sig. $\mathrm{t}=0.029)$ at $\mathrm{P}<0.05$, with higher levels of metals also recorded in sediments than water columns. The order of $\mathrm{I}_{\text {geo }}$ was $\mathrm{Fe}(5.959)>\mathrm{Zn}(4.932)>\mathrm{Cu}(4.743)>\mathrm{Mn}(4.326)>\mathrm{Pb}(3.214)>\mathrm{Ni}(2.483)>\mathrm{Cd}$ (1.649), AF was $\mathrm{Zn}(1.513)>\mathrm{Cd}(1.179)>\mathrm{Fe}(1.082)>\mathrm{Ni}(1.048)>\mathrm{Mn}(1.042)>\mathrm{Cu}$ $(1.032)>\mathrm{Pb}(0.987)$ and $\mathrm{PRC}$ was $\mathrm{Zn}(33.891)>\mathrm{Cd}(15.165)>\mathrm{Fe}(7.604)>\mathrm{Ni}(4.608)>\mathrm{Mn}$ $(4.047)>\mathrm{Cu}(3.052)>\mathrm{Pb}(-1.373)$. Active mining led to extreme contamination of the ponds with $\mathrm{Fe}$, strong to extreme contaminations with $\mathrm{Cu}, \mathrm{Zn}$ and $\mathrm{Mn}$, strong contamination with $\mathrm{Pb}$, moderate to strong contamination with $\mathrm{Ni}$ and moderate contamination with $\mathrm{Cd}$. However, $\mathrm{Pb}$ showed deficit recovery capacity and this could portend unfavourable ecological consequences on resident biota and raises public health concerns among resource dependants of the river. Strict enforcement of regulations on in-stream sand mining should be applied.
\end{abstract}

Keywords: in-stream sand mining, geoaccumulation index, pond recovery capacity, sediments.

\section{Acumulação e capacidade de recuperação de metais pesados em lagoas de mineração de areia do Rio Otamiri em Owerri, Nigéria}

\section{RESUMO}

Níveis, índice de acumulação e recuperação da capacidade de metais pesados $(\mathrm{Pb}, \mathrm{Cd}$, $\mathrm{Cu}, \mathrm{Ni}, \mathrm{Zn}, \mathrm{Fe}, \mathrm{Mn}$ ) em lagoas de mineração de areia do Rio Otamiri em Owerri, Nigéria, foram investigados durante a estação chuvosa de 2012. Amostras de água (WC) e de sedimentos (SD) foram coletadas em seis pontos de amostragem, sendo os pontos WC 1 - WC 3 e SD 1 - SD 3 localizados dentro de uma lagoa de mineração abandonada e WC 4 - WC 6 e 
SD 4 - SD 6 localizados dentro de uma lagoa de mineração ativa. $\mathrm{O}$ pH foi determinado in situ e os metais pesados determinados em espectrofotômetro de absorção atômica. O teste-t de Student, o índice de geoacumulação $\left(\mathrm{I}_{\mathrm{geo}}\right)$, o fator de acumulação (AF) e a capacidade de recuperação das lagoas (PRC) foram computados para as lagoas. Houve heterogeneidade espacial significativa nos níveis médios dos metais pesados nos sedimentos (sig. $t=0,029$ ) para $\mathrm{P}<0,05$, com níveis mais elevados de metais registrados nos sedimentos do que nas colunas de água. A ordem do $\mathrm{I}_{\text {geo }}$ foi $\mathrm{Fe}(5,959)>\mathrm{Zn}(4,932)>\mathrm{Cu}(4,743)>\mathrm{Mn}(4.326)>\mathrm{Pb}$ $(3,214)>\mathrm{Ni}(2,483)>\mathrm{Cd}(1,649)$, do AF foi $\mathrm{Zn}(1,513)>\mathrm{Cd}(1,179)>\mathrm{Fe}(1,082)>\mathrm{Ni}$ $(1,048)>\mathrm{Mn}(1,042)>\mathrm{Cu}(1,032)>\mathrm{Pb}(0,987)$ e da PRC foi de $\mathrm{Zn}(33,891)>\mathrm{Cd}(15,165)>$ $\mathrm{Fe}(7,604)>\mathrm{Ni}(4,608)>\mathrm{Mn}(4,047)>\mathrm{Cu}(3,052)>\mathrm{Pb}(-1,373)$. A mineração em atividade causou contaminação extrema da lagoa com $\mathrm{Fe}$, contaminações forte a extrema com $\mathrm{Cu}, \mathrm{Zn}$ e $\mathrm{Mn}$, contaminação forte com $\mathrm{Pb}$, contaminação moderada a forte com $\mathrm{Ni}$ e contaminação moderada com $\mathrm{Cd}$. No entanto, o $\mathrm{Pb}$ mostrou déficit de capacidade de recuperação e isso poderia trazer consequências ecológicas desfavoráveis na biota residente e gera preocupações com saúde pública entre os dependentes dos recursos do rio. Deve ser aplicada regulamentação rigorosa sobre mineração de areia nos cursos d'água.

Palavras-chave: mineração de areia em rios, índice de geoacumulação, capacidade de recuperação da lagoa, sedimentos.

\section{INTRODUCTION}

Sediment is used in a variety of ways to monitor and assess the overall health of the aquatic ecosystem, including the tracking of long-term monitoring programs relating to anthropogenic impacts. Other applications utilize macrobenthos, which are fauna living on or in the sediments as indicators of water quality (Ogbuagu et al., 2011); even as monitoring of recalcitrant pollutants such as the heavy metals have also been done using the sediment matrix (Lima, 2001; Baggio, 2008; Baggio and Heinrich, 2012).

In water pollution studies, sediment reflects not only the quality of the aquatic system, but also the contaminants that do not remain soluble after entry in surface waters. They act as carriers of potential pollution sources that are not permanently fixed and so are reservoirs for reintroduction of pollutant species, especially when perturbed in the face of changing environmental conditions such as $\mathrm{pH}$, redox potential and the presence of organic chelating agents (Baggio and Heinrich, 2012). Consequently, sediments have been characterized as natural barriers to pollutants due to the reactions of sorption, solubility, precipitation and complexation caused by contaminants and control parameters such as $\mathrm{pH}$, Eh, as well as sediment texture, particle size, proportion and types of clay minerals, among others (Meurer et al., 2000).

The Otamiri River is one of the major surface waters that serve the city of Owerri in southeastern Nigeria, providing for domestic source of water, fisheries and artisanal sand mining by the inhabitants. In recent times, the demands of increasing population and associated urbanization have placed serious pressure on such sediment resources of the river as sand, mostly used for buildings and other infrastructural constructions in the city. Concurrently, several mine ponds have been created as relics of river-bank mining along the course of the river, even as some are still currently mined in the study area. These semi-lentic ponds could thus harbour pollutants for a longer residency time of possible recovery from pollution loadings.

Being a reservoir for several pollutants such as heavy metals, an increase of in-stream sand mining could perturb the sink and re-introduce these pollutants into water column in higher, toxic levels. Though the process of self-purification could alleviate pollutant loadings in the derelict mine ponds (Ernestova and Seminova, 1994), this has not been investigated in 
the study area. This study therefore investigated the levels of heavy metals, their accumulation index and recovery potentials in sand mine ponds in line with effective pollution management and resource sustainability.

\section{MATERIALS AND METHODS}

\subsection{Study Area}

Owerri lies within latitude $05^{\circ} 29^{\prime} 06 \mathrm{~s}$ and longitude $07^{\circ} 02^{\prime} 06 \mathrm{~s}$ in southeastern Nigeria (Figure 1). The city experiences a wet season from April to November and a dry season for the rest of the year (Victor et al., 2011). Mean daily maximum temperature is between 28 and $35{ }^{\circ} \mathrm{C}$, while daily minimum values range between 19 and $24{ }^{\circ} \mathrm{C}$. Average humidity of up to $80 \%$ prevails in the region. Semi-deciduous forest vegetation that had been altered by agricultural and other anthropogenic activities covers the area (Onweremadu et al., 2008) and the dominant top-soil is moderately humus in composition. The Otamiri River is one of the two major surface waters that traverse the city.

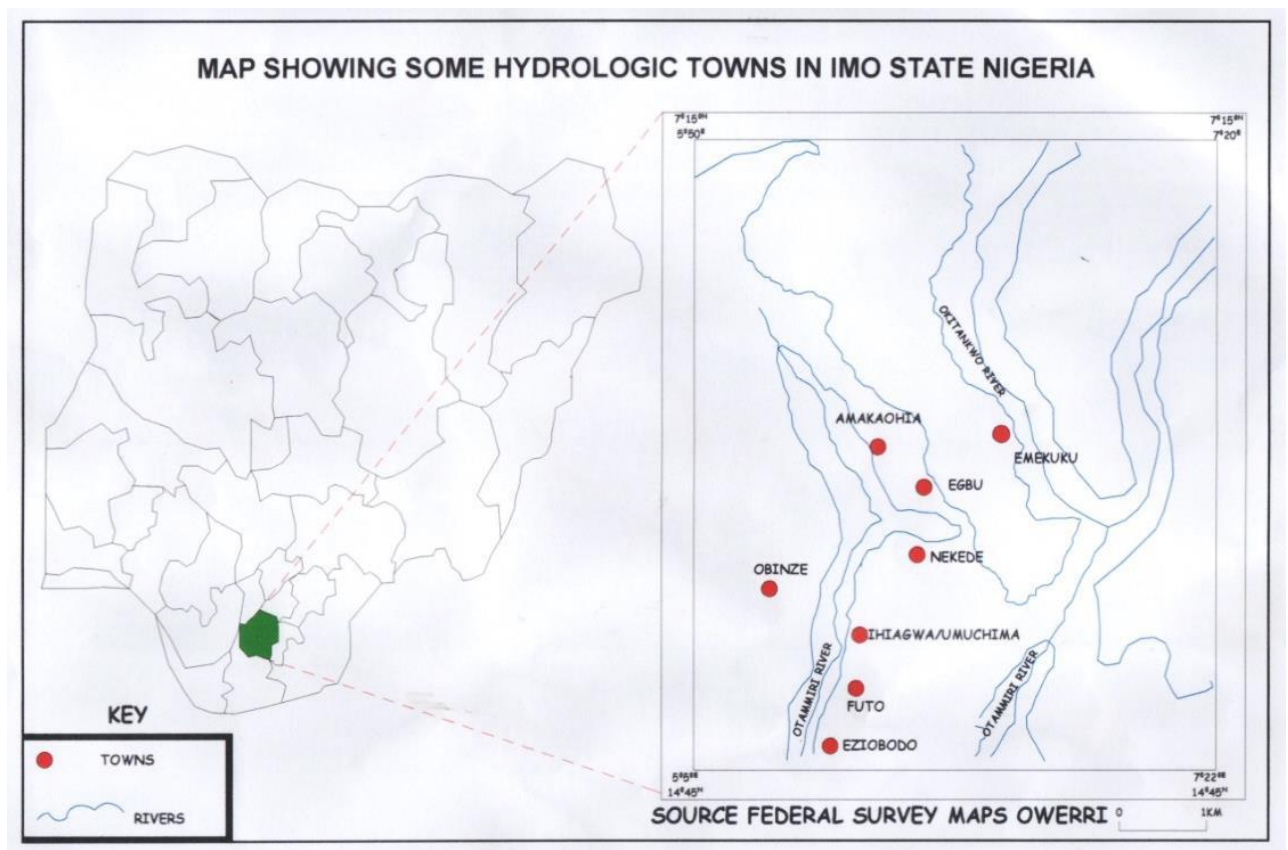

Figure 1. Location map of Nigeria showing Otamiri River in Owerri, Imo State.

\subsection{Field Sampling}

\subsubsection{Sampling locations}

Six sampling points were established about $30 \mathrm{~m}$ apart at the middle course of the river, between Nekede and Eziobodo, and were designated as WC 1-WC 6 and SD 1-SD 6 for water column and sediment samples respectively; with WC 1-WC 3 and SD 1-SD 3 located within a derelict mine pond and WC 4-WC 6 and SD 4-SD 6 located within a pond where active mining was ongoing. Samples were collected and taken to the laboratory as soon as possible on same day and according to standard methods of APHA et al. (1998).

\subsubsection{Field measurements}

In situ determination of $\mathrm{pH}$ was made with a pre-calibrated HANNA HI 9828 $\mathrm{pH} / \mathrm{ORP} / \mathrm{EC} / \mathrm{DO}$ meter in water columns and sediments of the ponds.

\subsection{Laboratory Analysis}


The levels of the heavy metals were determined by the atomic absorption spectrophotometric method (APHA et al., 1998). $5 \mathrm{~g}$ of sediment sample was weighed into $500 \mathrm{~mL}$ flask, $10 \mathrm{~mL}$ of $\mathrm{HNO}_{3}$ was added, and the sample was digested by heating in a fume chamber. $10 \mathrm{~mL}$ of distilled water was added and the sample was filtered. Direct aspiration of digested samples (including water column samples) was carried out into an air/acetylene flame generated by a hollow cathode lamp at a specific wavelength peculiar only to the metals.

\subsection{Statistical Analysis}

The student's t-test of significance was used to compare levels of heavy metals in the derelict and actively mined ponds. The index of geoaccumulation $\left(\mathrm{I}_{\mathrm{geo}}\right)$, given as:

$\mathbf{I}_{\mathbf{g e o}}=\ln \left(\mathbf{C}_{\mathrm{n}} / \mathbf{1 . 5} \mathbf{B}_{\mathrm{n}}\right)$ (Müller, 1979), (where $\mathrm{C}_{\mathrm{n}}=$ measured level of element $\mathrm{n}, \mathrm{B}_{\mathrm{n}}=$ geochemical background level of element $n$, and 1.5 is factor representing possible variations of background data due to lithogenic impacts) and accumulation factor (AF) given as:

$\mathbf{A F}=$ average level of a given parameter downstream/corresponding average level

Upstream (Fakayode, 2005) were used to estimate accumulation of the heavy metals in sediments of the ponds. Pond recovery capacity (PRC) (Ernestova and Seminova, 1994, as modified by Fakayode, 2005), and given as:

$\mathbf{P R C}=\left(\mathbf{S}_{\mathbf{0}}-\mathbf{S}_{\mathbf{1}}\right) / \mathbf{S}_{\mathbf{0}} \mathbf{X} \mathbf{1 0 0 \%}$ (where $\mathrm{S}_{0}=$ level of a parameter downstream, $\mathrm{S}_{1}=$ corresponding average level of the parameter upstream) was also computed for the metal pollutants.

\section{RESULTS}

\subsection{Levels of heavy metals in water columns and sediments}

At the $\mathrm{pH}$ ranges of 3.76-4.42 (4.03 \pm 0.10$)$ and 3.99-4.38 (4.17 \pm 0.07$)$, the levels of the heavy metals varied as follows: $\mathrm{Pb}, 0.28-0.95(0.69 \pm 0.12) \mathrm{mg} \mathrm{L}^{-1}$ and $4.30-7.88$ $(6.11 \pm 0.54) \mathrm{mg} \mathrm{kg}^{-1}$; Cd, 0.64-1.58 (1.12 \pm 0.15$) \mathrm{mg} \mathrm{L}^{-1}$ and 2.41-3.70 (2.80 \pm 0.19$) \mathrm{mg} \mathrm{kg}^{1}$; $\mathrm{Cu}, 4.00-6.40(5.04 \pm 0.38) \mathrm{mg} \mathrm{L}^{-1}$ and 10.80-16.45 (13.12 \pm 0.97$) \mathrm{mg} \mathrm{kg}^{-1} ; \mathrm{Ni}, 1.20-1.92$ $(1.60 \pm 0.11) \mathrm{mg} \mathrm{L}^{-1}$ and 3.18-6.00 (4.24 \pm 0.42$) \mathrm{mg} \mathrm{kg}^{-1} ; \mathrm{Zn}, 4.50-6.20(5.17 \pm 0.26) \mathrm{mg} \mathrm{L}^{-1}$ and $9.20-20.82(14.73 \pm 1.81) \mathrm{mg} \mathrm{kg}^{-1}$; Fe, 5.80-8.82 (7.13 \pm 0.44$) \mathrm{mg} \mathrm{L}^{-1}$ and 20.20-28.60 $(24.12 \pm 1.63) \mathrm{mg} \mathrm{kg}^{-1}$; Mn, 2.50-4.80 (3.15 \pm 0.35$) \mathrm{mg} \mathrm{L}^{-1}$ and 10.00-11.80 (10.65 \pm 0.26$)$ $\mathrm{mg} \mathrm{kg}{ }^{-1}$ in water columns and sediments respectively. However, $\mathrm{Hg}$, As and Co were undetected in both water columns and sediment samples.

\subsection{Spatial variations in levels of heavy metals}

In the water columns, minimum $\left(0.28 \mathrm{mg} \mathrm{L}^{-1}\right)$ and maximum levels of $\mathrm{Pb}\left(0.95 \mathrm{mg} \mathrm{L}^{-1}\right)$ were recorded in WC 6 and WC 1, while in sediments, minimum and maximum levels of 4.30 and $7.88 \mathrm{mg} \mathrm{kg}^{-1}$ were recorded in SD 5 and SD 6 respectively (Figure 2). Minimum and maximum levels of $\mathrm{Cd}$ in water columns $\left(0.64\right.$ and $\left.1.58 \mathrm{mg} \mathrm{L}^{-1}\right)$ were recorded in WC 6 and WC 2 while in sediments, minimum and maximum values of 1.80 and $3.70 \mathrm{mg} \mathrm{kg}^{-1}$ were recorded in SD 6 and SD 5 respectively (Figure 3). However, for $\mathrm{Cu}$ (Figure 4) and $\mathrm{Ni}$ (Figure 5) in the water columns, minimum $\left(4.00 \& 1.20 \mathrm{mg} \mathrm{L}^{-1}\right)$ and maximum levels $\left(6.40 \& 1.92 \mathrm{mg} \mathrm{L}^{-1}\right)$ were recorded in WC $6 \& \mathrm{WC} 1$, and WC $1 \& \mathrm{WC} 3$, and in the sediments, minimum $\left(10.80 \& 3.42 \mathrm{mg} \mathrm{kg}^{-1}\right)$ and maximum levels $\left(16.45 \& 6.00 \mathrm{mg} \mathrm{kg}^{-1}\right)$ were recorded in SD 1 \& SD 3, and SD 4 \& SD 6 respectively.

In the water columns, $\mathrm{Zn}, \mathrm{Fe} \& \mathrm{Mn}$ recorded minimum levels of $4.50,5.80 \& 2.50 \mathrm{mg} \mathrm{L}^{1}$ in WC 6, WC 3 \& WC 1, while the respective maximum levels of $6.20,8.82 \& 4.80 \mathrm{mg} \mathrm{L}^{-1}$ were recorded in WC 1 (Figure 6), WC 4 (Figure 7) \& WC 5 (Figure 8). However, in 
sediments, minimum levels $\left(9.20,20.20 \& 10.00 \mathrm{mg} \mathrm{kg}^{-1}\right)$ were recorded in SD 1, SD 1 \& SD 2, while maximum levels $\left(20.82,28.60 \& 11.80 \mathrm{mg} \mathrm{kg}^{-1}\right)$ were recorded in SD 4, SD 6 \& SD 5 respectively.

A pair-wise student's t-test in pooled levels of the heavy metals between the actively mined (WC\&SD 4- WC\&SD 6) and derelict ponds (WC\&SD 1- WC\&SD 3) revealed significant heterogeneity ( sig. $\mathrm{t}=0.029$ ) in sediment samples but homogeneity (sig. $\mathrm{t}=0.686$ ) in water columns at $\mathrm{P}<0.05$.

\subsection{Index of accumulation and recovery capacity}

A transition in levels of the heavy metals from the sediments of the actively mined to the derelict ponds revealed that Fe showed the highest $\mathrm{I}_{\text {geo }}$ (5.959) and $\mathrm{Zn}$ the highest $\mathrm{AF}$ (1.513) and PRC (33.891) (Table 1). Of the detectable metals however, while the least $\mathrm{I}_{\text {geo }}$ was exhibited in Cd (1.649), least AF (0.987) and even deficit PRC (-1.373) were exhibited in $\mathrm{Pb}$ concentrations in sediments. Between the actively mined and derelict ponds, the order of $\mathrm{I}_{\text {geo }}$ was $\mathrm{Fe}>\mathrm{Zn}>\mathrm{Cu}>\mathrm{Mn}>\mathrm{Pb}>\mathrm{Ni}>\mathrm{Cd}, \mathrm{AF}$ was $\mathrm{Zn}>\mathrm{Cd}>\mathrm{Fe}>\mathrm{Ni}>\mathrm{Mn}>\mathrm{Cu}>\mathrm{Pb}$ and $\mathrm{PRC}$ was $\mathrm{Zn}>$ $\mathrm{Cd}>\mathrm{Fe}>\mathrm{Ni}>\mathrm{Mn}>\mathrm{Cu}>\mathrm{Pb}$.

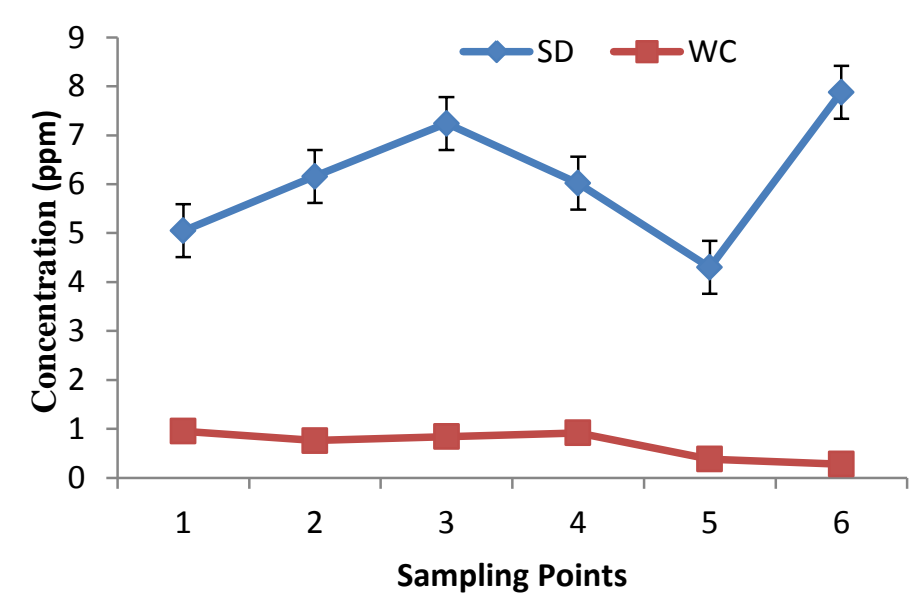

Figure 2. Spatial variations in levels of lead in sediments and water columns of Otamiri River, Owerri.

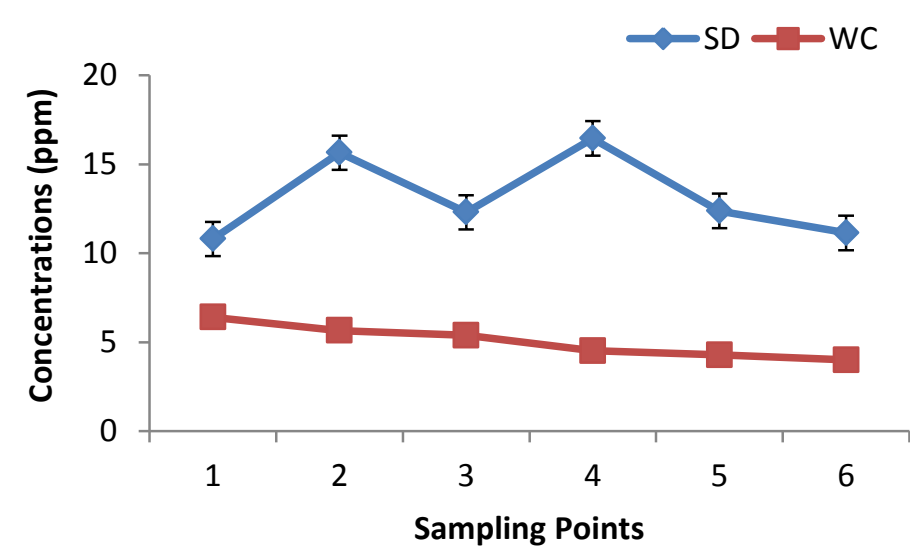

Figure 4. Spatial variations in levels of copper in sediments and water columns of Otamiri River, Owerri.

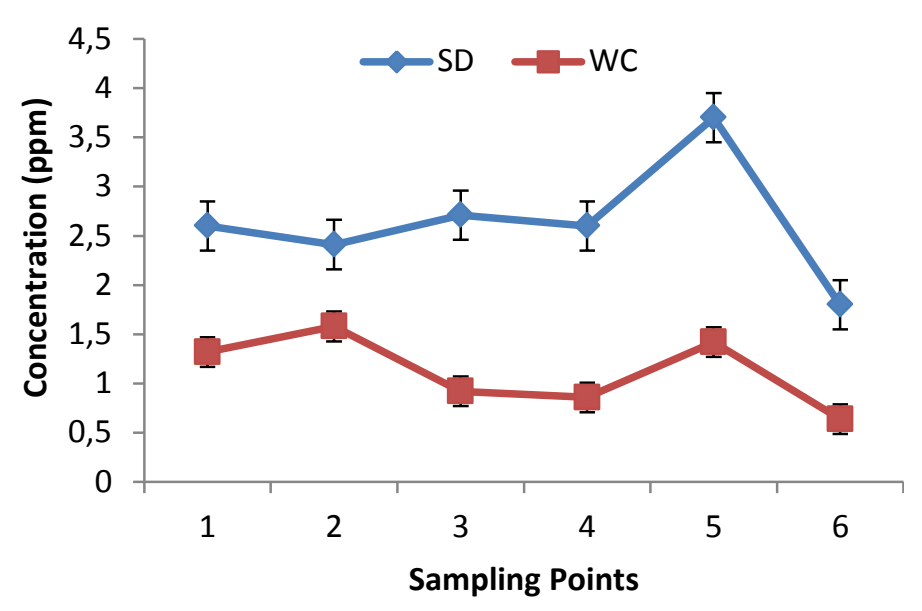

Figure 3. Spatial variations in levels of cadmium in sediments and water columns of Otamiri River, Owerri.

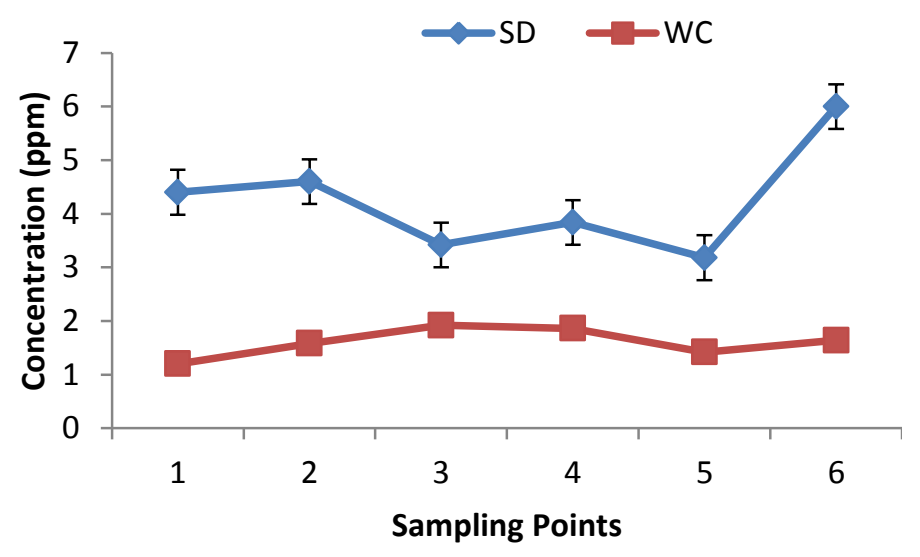

Figure 5. Spatial variations in levels of nickel in sediments and water columns of Otamiri River, Owerri. 


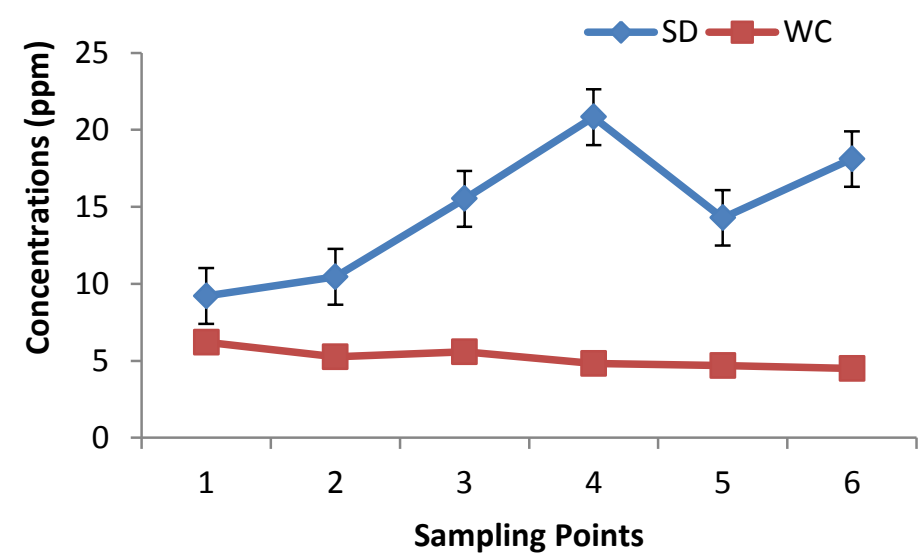

Figure 6. Spatial variations in levels of zinc in sediments and water columns of Otamiri River, Owerri.

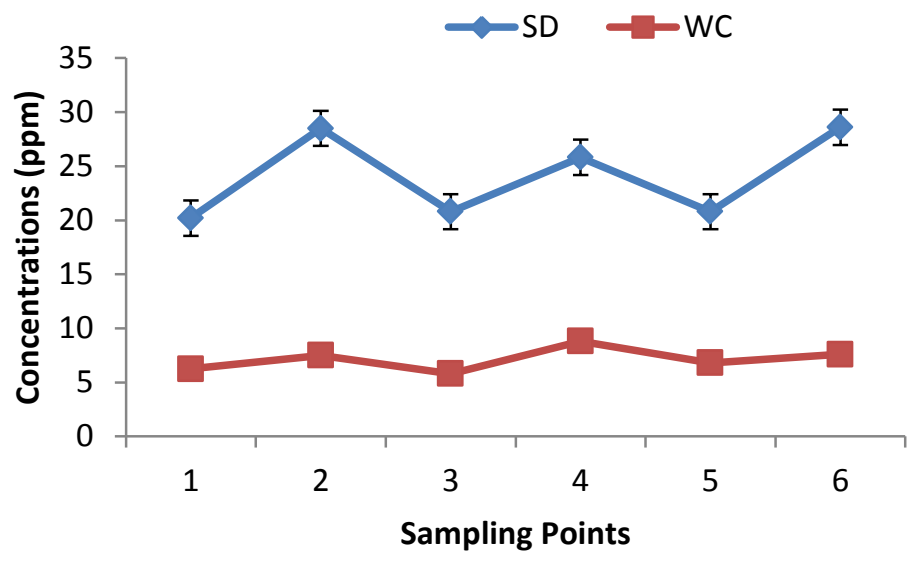

Figure 7. Spatial variations in levels of iron in sediments and water columns of Otamiri River, Owerri.

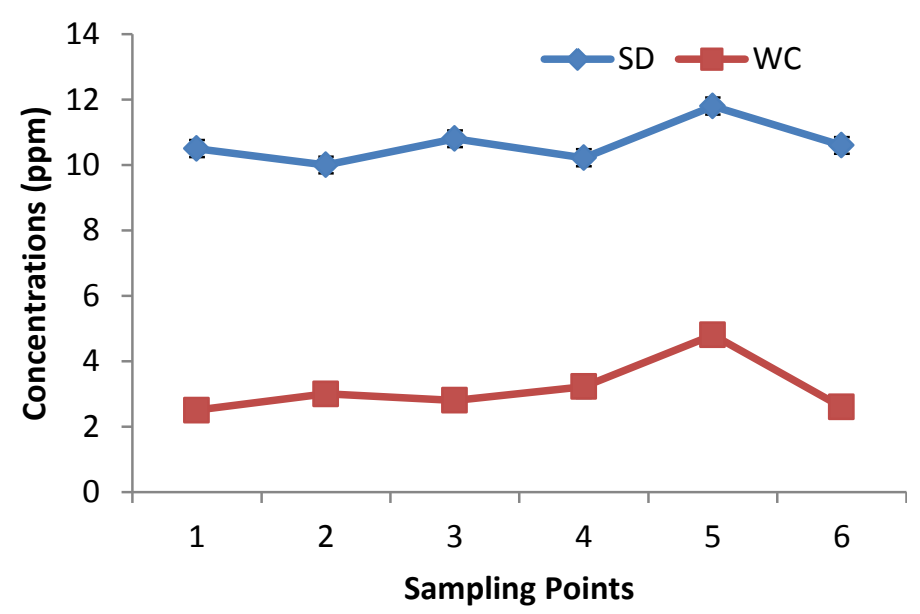

Figure 8. Spatial variations in levels of manganese in sediments and water columns of Otamiri River, Owerri.

Table 1. Index of geoaccumulation ( $\left.\mathrm{I}_{\mathrm{geo}}\right)$, accumulation factor (AF) and pond recovery capacity (PRC) of mine ponds of the Otamiri River in Owerri.

\begin{tabular}{c|cccc}
\hline S/No & $\begin{array}{c}\text { Heavy } \\
\text { Metals }\end{array}$ & $\mathbf{I}_{\text {geo }}$ & AF & PRC (\%) \\
\hline 1 & $\mathrm{~Pb}$ & 3.214 & 0.987 & -1.373 \\
2 & $\mathrm{Hg}$ & 0.000 & 0.000 & 0.000 \\
3 & $\mathrm{As}$ & 0.000 & 0.000 & 0.000 \\
4 & $\mathrm{Cd}$ & 1.649 & 1.179 & 15.165 \\
5 & $\mathrm{Cu}$ & 4.743 & 1.032 & 3.052 \\
6 & $\mathrm{Ni}$ & 2.483 & 1.048 & 4.608 \\
7 & $\mathrm{Zn}$ & 4.932 & 1.513 & 33.891 \\
8 & $\mathrm{Fe}$ & 5.959 & 1.082 & 7.604 \\
9 & $\mathrm{Mn}$ & 4.326 & 1.042 & 4.047 \\
10 & $\mathrm{Co}$ & 0.000 & 0.000 & 0.000 \\
\hline
\end{tabular}




\section{DISCUSSION}

The levels of all the detected heavy metals exceeded regulatory limits set by the Federal Ministry of Environment (Nigeria, 2001) and the National Environmental Standards and Regulations Enforcement Agency (NESREA, 2011) in Nigeria. This portends toxicity risks to aquatic biota through possible bioaccumulation and ultimately to human consumers of the resources. Accordingly, Braga (2002) stated that water contamination prevents its use for human consumption. Apparently, lentic zones such as these ponds could serve as brooding grounds for aquatic organisms and elevated contaminations with these recalcitrant pollutants could expose the organisms, especially juveniles, to toxicity. Therefore, when evaluating pollution and the quality of aquatic systems, it is important to take into consideration possible contamination by sediments deposited around ponds, apart from detecting contaminants that do not remain soluble after launched in water column (Lima, 2001).

The higher levels of heavy metals in the sediments than in the water columns rightly indicate the repository role of sediments in aquatic environments (Axtmann and Luoma, 1991; Ogbuagu et al., 2011; Baggio and Heinrich, 2012).

The significantly variant levels of the pollutants between the actively mined and derelict ponds indicate the effects of perturbations created by in-stream mining. The higher concentrations of $\mathrm{Pb}, \mathrm{Cd}, \mathrm{Cu}, \mathrm{Ni}$ and $\mathrm{Zn}$ in the water columns and of $\mathrm{Pb}, \mathrm{Cd}$ and $\mathrm{Cu}$ in the sediments of the derelict rather than the actively mined ponds reflects the ceasing of removal of the metals through sediment excavations during mining. However, the higher concentrations of $\mathrm{Fe}$ and $\mathrm{Mn}$ in the water columns and of $\mathrm{Ni}, \mathrm{Zn}, \mathrm{Fe}$ and $\mathrm{Mn}$ in the sediments of the actively mined than the derelict ponds suggests that these pollutants are more abundant in sediments and so get re-suspended in the water columns (Fe \& Mn) during active sediment excavations. Baggio and Heinrich (2012) further showed that sediments act as carriers of potential pollution sources, such as heavy metals, that are not permanently fixed and that they can be rearranged into the water column by changing environmental conditions, some of which are triggered by anthropogenic activities.

Going by the sediment quality of $\mathrm{I}_{\text {geo }}$ classifications (Müller, 1979), the actively mined ponds were extremely contaminated with $\mathrm{Fe}$, strongly to extremely contaminated with $\mathrm{Cu}, \mathrm{Zn}$ and $\mathrm{Mn}$, strongly contaminated with $\mathrm{Pb}$, moderately to strongly contaminated with $\mathrm{Ni}$ and moderately contaminated with $\mathrm{Cd}$. Reference to the two accumulation indices used indicates consistency in accumulations (though not in order) of all the detectable metals in sediments of the ponds. Thus, the major contaminants of ecological concern were $\mathrm{Fe}, \mathrm{Zn}, \mathrm{Cu}$ and $\mathrm{Cd}$. The least accumulating metals were $\mathrm{Cu}, \mathrm{Pb}, \mathrm{Ni}$ and $\mathrm{Cd}$.

Conversely, the sediments showed very low recoveries of less than $50 \%$ from pollutant loadings, and the most of these recoveries were in $\mathrm{Zn}, \mathrm{Cd}$ and $\mathrm{Fe}$, with $\mathrm{Pb}$ showing even deficit recovery. This implies recalcitrance in heavy metals pollution and further implicates $\mathrm{Pb}$ as the most persistent pollutant in sediments, especially in the derelict ponds. Though Xavier (2004) had stated that soil has the ability to immobilize and depurate most of the impurities deposited on it by acting as a filter for pollutants, in the case of multiple sources of contaminants resulting from anthropogenic impacts, this filtering capacity and self-purification could be compromised.

\section{CONCLUSION}

The levels of the detectable heavy metals were all above regulatory limits, with significantly higher concentrations in sediments than in water columns and variant levels between the actively mined and derelict sand mine ponds. $\mathrm{Hg}$, As and Co were undetected in both water columns and sediments of the mine ponds. Fe and $\mathrm{Zn}$ exhibited the highest 
geoaccumulation index and accumulation factor, while $\mathrm{Cd}$ and $\mathrm{Pb}$ exhibited the least geoaccumulation index and accumulation factor, respectively. However, the metals showed very low recoveries, especially in the derelict pond.

Sand mining activities appeared to be related to the presence and levels of heavy metals, as well as the self-purification capacity of the mine ponds.

\section{REFERENCES}

AMERICAN PUBLIC HEALTH ASSOCIATION- APHA; AMERICAN WATER WORKS ASSOCIATION - AWWA; WATER ENVIRONMENT FEDERATION - WEF. Standard methods for examination of water and wastewater. 20th ed. Washington DC, 1998.

AXTMANN, E. V.; LUOMA, S. N. Large-scale distribution of metal contamination in the fine-grained sediments of the Clark Fork River, Montana, U.S.A. Applied Geochemistry, v. 6, p. 75-88, 1991. http://dx.doi.org/10.1016/0883-2927(91)90064-V

BAGGIO, H. F. Contribuições naturais e antropogênicas para a concentração e distribuição de metais pesados em sedimento de corrente na bacia do Rio do Formoso, município de Buritizeiro. 2008. 234f. Tese (Doutorado) - Instituto de Geociências, Universidade Federal de Minas Gerais, Belo Horizonte, 2008.

BAGGIO, H.; HEINRICH, H. Natural and anthropogenic contributions to concentration and distribution of heavy metals in surface water and in stream sediments in the Formoso River, Buritizeiro municipality-Minas Gerais State, Brazil. Comunicações Geológicas, v. 99 , n. 2, p. 71-78, 2012.

BRAGA, L. L. Avaliação do impacto ambiental da usina de beneficiamento de Fe e Si, Várzea da Palma, MG, Brasil - distribuição e transporte dos contaminantes. 2002. 81f. Dissertação (Mestrado em Geologia Ambiental) - Instituto de Geociências, Universidade Federal de Minas Gerais, Belo Horizonte, 2002.

ERNESTOVA, L. S.; SEMENOVA, I. V. The self-purification capacity of natural water as an indicator of the ecological state of a water body. Water Resources, v. 21, n. 2, p. 146-150, 1994.

FAKAYODE, S. O. Impact assessment of industrial effluent on water quality of the receiving Alaro River in Ibadan, Nigeria. Ajeam-Ragee, v. 10, p. 1-13, 2005.

LIMA, M. J. Avaliação de metais e elementos-traço em águas e sedimentos das bacias hidrográficas dos rios Mogi-Guaçu e Prado, São Paulo. 2001. 210f. Tese (Mestrado) - Instituto de Pesquisas Energéticas e Nucleares, São Paulo, 2001.

MEURER, E. J.; BASSANI, C. A.; SELBACH, P. A. Poluentes dos solos e do ambiente. In: MEURER, E. J. Fundamentos de química dos solos. Porto Alegre: Gênesis, 2000. P. 151-174.

MÜLLER, G. Schwermetalle in den sedimenten des Rheins-Veränderungen seit 1971. Umschau, v. 79, p. 778-783, 1979.

NATIONAL ENVIRONMENTAL STANDARDS AND REGULATIONS ENFORCEMENT AGENCY - NESREA. National environmental (Surface and groundwater quality control) regulations. Federal Republic of Nigeria Official Gazette, v. 98, n. 49, 2011. 
NIGERIA. Ministry of Environment - FME. National guidelines and standards for water quality in Nigeria. Rishab Printing Press Production, 2001. p. 114.

OGBUAGU, D. H.; NJOKU, J. D.; AYOADE, A. A. Trends in macrobenthal biotypes of Imo River in a Nigerian Delta region. Journal of Biodiversity and Environmental Sciences (JBES), v. 1, n. 4, p. 22-28, 2011.

ONWEREMADU, E. U.; AKAMIGBO, F.; IGWE, C. A. Soil quality morphological index in relation to organic carbon content of soils in southwestern Nigeria. Trends in Applied Science Research, v. 3, n. 1, p. 76-82, 2008.

VICTOR, S.; AC-CHUKWUOCHA, N. B.; OGBUAGU, D. H. Trace metals availability in soils of watershed in relation to land use in Owerri, southeastern Nigeria. Journal of Science and Sustainability, v. 3, p. 3-12, 2011.

XAVIER, L. L. Análise de risco ambiental em cenários de contaminação de solos: uma avaliação metodologica comparativa. 2004. 250f. Dissertação (Mestrado) Universidade Federal de Minas Gerais, Belo Horizonte, 2004. 